University of Nebraska - Lincoln

DigitalCommons@University of Nebraska - Lincoln

Biological Systems Engineering: Papers and

Publications

2017

\title{
Evaluation of Valiantzas' Simplified Forms of the FAO-56 Penman- Monteith Reference Evapotranspiration Model in a Humid Climate
}

Koffi Djaman

Daran Rudnick

Valere C. Mel

Denis Mutiibwa

Lamine Diop

See next page for additional authors

Follow this and additional works at: https://digitalcommons.unl.edu/biosysengfacpub

Part of the Bioresource and Agricultural Engineering Commons, Environmental Engineering Commons, and the Other Civil and Environmental Engineering Commons

This Article is brought to you for free and open access by the Biological Systems Engineering at DigitalCommons@University of Nebraska - Lincoln. It has been accepted for inclusion in Biological Systems Engineering: Papers and Publications by an authorized administrator of DigitalCommons@University of Nebraska Lincoln. 


\section{Authors}

Koffi Djaman, Daran Rudnick, Valere C. Mel, Denis Mutiibwa, Lamine Diop, Mamadou Sall, Isa Kabenge, Ansoumana Bodian, Hossein Tabari, and Suat Irmak 


\title{
Evaluation of Valiantzas' Simplified Forms of the FAO-56 Penman-Monteith Reference Evapotranspiration Model in a Humid Climate
}

\author{
Koffi Djaman, ${ }^{1}$ Daran Rudnick, ${ }^{2}$ Valere C. Mel, ${ }^{3}$ \\ Denis Mutiibwa, ${ }^{4}$ Lamine Diop, ${ }^{5}$ Mamadou Sall, ${ }^{6}$ \\ Isa Kabenge, ${ }^{7}$ Ansoumana Bodian, ${ }^{8}$ Hossein Tabari, ${ }^{9}$ \\ and Suat Irmak, M.ASCE ${ }^{10}$
}

1 Agronomist, Africa Rice Center, Regional Sahel Station, B.P. 96 St Louis, Senegal (corresponding author). E-mail: k.djaman@cgiar.org

2 Assistant Professor, Department of Biological Systems Engineering, University of Nebraska-Lincoln, Chase Hall, Lincoln, NE 68583-0726.

3 Research Assistant, Africa Rice Center, Regional Sahel Station, B.P. 96 St Louis, Senegal.

4 Research Scientist, Department of Geography, University of Nevada, 1664 N Virginia St., Reno, NV 89557.

5 Lecturer, UFR S2ATA Sciences Agronomiques, d'Aquaculture et des Technologies Agroalimentaires, Université Gaston Berger, BP 234 St Louis, Sénégal.

6 Research Scientist, Institut Senegalais de Recherches Agricoles, Centre de Saint Louis, BP 240 St Louis, Sénégal.

7 Lecturer, Department of Agricultural and Biosystems Engineering, Makerere University, P.O. Box 7062, Kampala, Uganda.

8 Lecturer, Laboratoire Leïdi Dynamique des Territoires et Développement, Université Gaston Berger, BP 234 St Louis, Sénégal.

9 Research Assistant, Department of Civil Engineering, UK Leuven, Hydraulics Division, Kasteelpark Arenberg 40, BE-3001 Leuven, Belgium.

10 Distinguished Professor, Department of Biological Systems Engineering, University of Nebraska-Lincoln, 241 L. W. Chase Hall, Lincoln, NE 68583- 0726.

Published in Journal of Irrigation and Drainage Engineering, 2017, 143(8): 06017005 DOI: 10.1061/(ASCE)IR.1943-4774.0001191

Copyright (c) 2017 American Society of Civil Engineers. Used by permission.

Submitted September 6, 2016; approved January 9, 2017; published March 23, 2017. 


\begin{abstract}
The unavailability of some meteorological variables, especially solar radiation and wind speed, is the main constraint for reference evapotranspiration (ETo) estimation using the standard United Nations Food and Agriculture Organization (FAO) Penman-Monteith (FAO-PM) equation in most developing countries. The application of ETo methods with fewer input requirements is necessary under limited climatic data conditions. The FAO-PM method under limited data conditions and nine of Valiantzas' equations were evaluated for daily ETo estimation in a humid climate in Uganda. The FAO-PM method with missing relative humidity data performed very well across Uganda, whereas using the long-term local wind speed average values in place of missing wind speed data resulted in inaccurate ETo estimates. Under missing solar radiation measurements, the FAO-PM method showed different performances relative to the locations. When more than one climatic variable is missing, the FAO-PM method yielded poor ETo estimates compared to the FAO-PM method with full climatic data. The performance of Valiantzas' equations depends on data requirements: the more meteorological inputs, the higher the ETo accuracy.
\end{abstract}

Keywords: Reference evapotranspiration, Penman-Monteith, Valiantzas, Limited data, Humid climate

\title{
Introduction
}

Crop evapotranspiration (ET) is a critical parameter in hydrological studies and plays an important role in water resource management in hydrological, agricultural, and environmental studies. Under a changing climate, water scarcity requires effective water management through accurate crop water use estimation under a regime of irrigated and rainfed agriculture. A simplified and commonly used method for estimating crop ET is the two-step approach, which relates crop reference evapotranspiration (ETo) to crop-specific coefficients (Kc) (Djaman and Irmak 2013; Rudnick and Irmak 2014). Crop ETo can be estimated using different methods, such as direct measurement from a reference crop like perennial grass or alfalfa (Doorenbos and Pruitt 1977), computation from weather data using temperature, relative humidity, wind speed, solar radiation, and combination-based energy balance models (Thornthwaite 1948; Doorenbos and Pruitt 1977; Hargreaves and Samani 1985; Allen et al. 1998; ASCE-EWRI 2005). McMahon et al. (2016) presented a comprehensive review on evaporation measurement and modeling and reported on 166 evaporation models developed and used elsewhere across the globe. 
Of the well-known studies, the FAO-56 Penman-Monteith (FAOPM) model was shown to be the most accurate computational method under different climatic conditions (e.g., Allen et al. 1998; Irmak et al. 2003; Hargreaves and Allen 2003; Garcia et al. 2004; López-Urrea et al. 2006; Irmak et al. 2008; Jabloun and Sahli 2008; Xing et al. 2008; Trajkovic and Kolakovic 2009; Martinez and Thepadia 2010; Tabari et al. 2013; Xystrakis and Matzarakis 2011; Azhar and Perera 2011; Djaman et al. 2015, 2016a, b, c). Thus, the standardized PM model has been recommended for ETo estimation across the globe (Allen et al. 1998; ASCE-EWRI 2005). Utset et al. (2004) also reported that FAO-PM is the most accurate model in the semiarid Mediterranean climate in Zaragoza, Spain. Mendonça et al. (2003) reported that the FAO-PM method provided the best ETo estimates compared to lysimeter data in the tropical humid climate at Pesagro-Rio in Brazil.

The FAO-PM method requires a full data set of climatic variables, such as maximum and minimum air temperature (Tmax and Tmin), maximum and minimum relative humidity (RHmax and RHmin), wind speed $(u)$ at $2 \mathrm{~m}$ height, and short wave solar radiation (Rs). However, the climatic variables required for FAOPM are often incomplete or not available in most developing countries, including Uganda. Some of these variables, especially short wave solar radiation (Rs) and wind speed $(u)$, are often missing from weather stations in developing countries, and this is the main constraint on the use of the model in locations where climate data are limited (Stockle et al. 2004; Irmak et al. 2008; Jabloun and Sahli 2008; Trajkovic and Kolakovic 2009; Li et al. 2012; Rahimikhoob et al. 2012; Tegos et al. 2013, 2015; Djaman et al. 2016a, b, c). Therefore, the application of simple ETo models with fewer meteorological parameter requirements is necessary in situations where more complete weather data are lacking.

From a cross comparison of 31 ETo methods in Iran, only five methods were revealed to have reliable performance compared to the FAOPM model (Tabari et al. 2013). In Florida, Martinez and Thepadia (2010) demonstrated that the Turc ETo equation is recommended for estimating ETo in the absence of regionally calibrated methods, whereas the Hansen and Turc equations were the most useful with the least average monthly error in Greece (Xystrakis and Matzarakis 2011). Jabloun and Sahli (2008) verified that the FAO-PM model using only Tmax and Tmin provided satisfactory ETo estimates compared to the FAO-PM 
model using full data in various semiarid locations in Tunisia. Sentelhas et al. (2010) reported that when $\mathrm{RH}$ and $u$ data were missing, the FAO-PM method was still a reliable option for estimating ETo for southern Ontario, with a root-mean-square error (RMSE) smaller than $0.53 \mathrm{~mm} /$ day when adopting the regional average wind speed and actual vapor pressure estimated from the minimum temperature data. In contrast, the ETo estimated after deriving solar radiation from Tmax and Tmin consistently overestimated daily ETo compared with the full FAO-PM method for all months and locations in Mississippi, a humid region of the USA (Fisher and Pringle 2013).

Regarding the importance of accurate estimation of ETo by the FAO-PM method in data-limited conditions, recent studies (Valiantzas 2013a, b, c, d) have managed to simplify the estimation method with good performance and accuracy, even under conditions of limited data availability. The Valiantzas equations were developed based on climatic data from the Northern Hemisphere and correlated well with the values obtained using the FAO-PM method. Djaman et al. (2015, 2016b), Valipour $(2014,2015)$, and Kisi (2014) have tested the performance of the simplified models developed by Valiantzas. Valiantzas suggested different equations for estimating ETo, as a function of the availability of climatic data on a local scale (Valiantzas 2012). Three of Valiantzas' equations (Valiantzas 2006, 2013c, d) were evaluated in the Pilbara region of Western Australia, and two of them are suitable for estimating ETo in the study area, but their performance was improved by calibrating them to local climatic conditions (Ahooghalandari et al. 2016). The Valiantzas equation with a full data set was shown to be suitable in the semiarid Sahelian climate of Senegal (Djaman et al. 2015) and in Burkina Faso (Djaman et al. 2016b) and in the humid and semiarid climate in Tanzania and southwestern Kenya (Djaman et al. 2016a).

Valipour (2014) investigated three of Valiantzas' equations across Iran and found Valiantzas $1\left(T, R_{s^{\prime}} R H, u\right)$ to be more suitable for central and southern Iran, Valiantzas $2\left(T, R_{s^{\prime}} R H, u\right)$ for western, eastern, and northern Iran, and Valiantzas $3\left(T, R_{s^{\prime}} R H\right)$ under limited data conditions. He indicated that Valiantzas' equations performed better under a daily Rs of greater than $24.2 \mathrm{MJ} / \mathrm{m}^{2}$, a temperature range of $16-$ $18^{\circ} \mathrm{C}$, a $\mathrm{RH}$ range of $40-50 \%$, and a $u$ range of $1.50-2.50 \mathrm{~ms}$.

While several studies have provided valuable information on the accuracy of some of Valiantzas' equations elsewhere, very limited 
support data and information are available on the applicability of different Valiantzas equations in the tropical humid climate of Africa across the equator. Thus, this study aimed to evaluate the PM ETo model under conditions of limited data, evaluate nine of Valiantzas' ETo equations, and identify the best performing models to adopt at the country level of ETo estimation under the conditions of the humid climate in Uganda.

\section{Material and Methods}

\section{Study Area and Meteorological Data Used}

Meteorological data required for the FAO-56 Penman-Monteith (PMETo) and Valiantzas' model implementations were collected from across Uganda from 1992 to 2012 at 4 meteorological stations (Arua, Masindi, Soroti, and Tororo), from 1998 to 2012 at 11 stations (Buginyanya-Kachorwa, Bulindi, Entebbe, Gulu, Kabale, Kabanyolo, Kasese, Kibbanda-Rakai, Kitgum, Lira, Namulonge), and from 1995 to 2012 at 1 station (Mbarara). Daily average solar radiation (Rs), minimum temperature (Tmin), maximum temperature (Tmax), minimum relative humidity (RHmin), maximum relative humidity (RHmax), and wind speed (u) were monitored at all 16 weather stations during the study period. Fig. 1 presents the geographical distribution of the study sites across Uganda, and a summary of the long-term average climatic data is presented in Table 1.

\section{Reference Evapotranspiration Equations}

\section{Penman-Monteith Model (PM-ETo)}

Daily grass-reference ET was computed using the standardized ASCE form of the Penman-Monteith (PM-ETo) equation (Allen et al. 1998):

$$
E T o=\frac{0.408 \Delta(R n-G)+\left[\gamma C n u_{2} /(T+273)\right](e s-e a)}{\Delta+\gamma\left(1+C d u_{2}\right)}
$$

where $E T o=$ reference evapotranspiration $(\mathrm{mm} /$ day); $\Delta=$ slope of saturation vapor pressure versus air temperature curve $\left(\mathrm{kPa} /{ }^{\circ} \mathrm{C}\right) ; R n=$ 


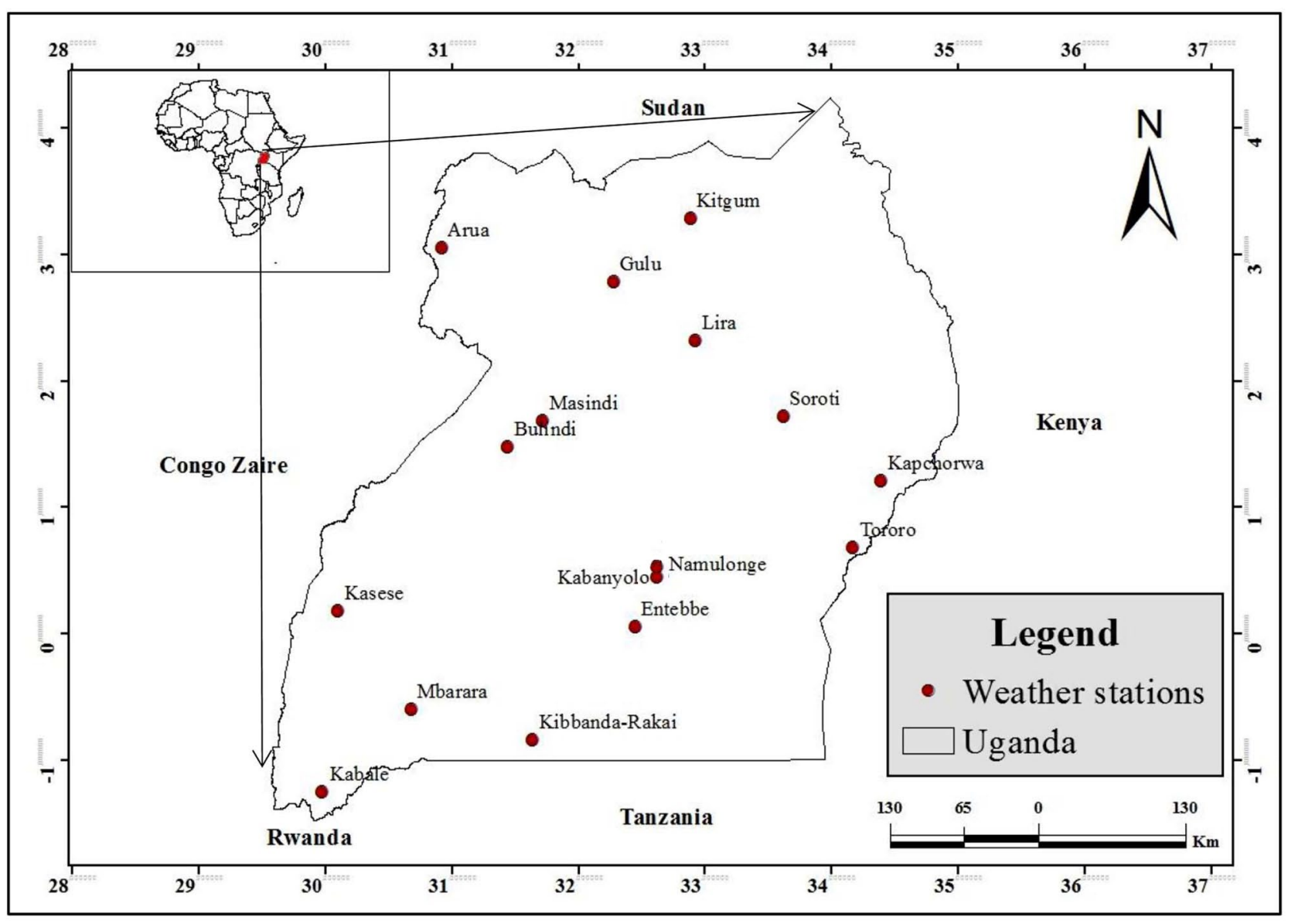

Fig. 1. Map of Uganda showing weather stations used in current study

Table 1. Meteorological Stations with Long-Term Annual Average Climatic Variables

\begin{tabular}{|c|c|c|c|c|c|c|c|c|c|c|}
\hline Weather station & $\begin{array}{l}\text { Latitude } \\
\text { DDNorth }\end{array}$ & $\begin{array}{r}\text { Longitude } \\
\text { DDEast }\end{array}$ & $\begin{array}{r}\text { Altitude } \\
\text { (m) }\end{array}$ & $\begin{array}{r}u_{2} \\
(m / s)\end{array}$ & $\begin{array}{r}T \max \\
\left({ }^{\circ} \mathrm{C}\right)\end{array}$ & $\begin{array}{r}T \min \\
\left({ }^{\circ} \mathrm{C}\right)\end{array}$ & $\begin{array}{r}\text { Rhmax } \\
\text { (\%) }\end{array}$ & $\begin{array}{r}\text { Rhmin } \\
\text { (\%) }\end{array}$ & $\begin{array}{r}R s \\
\left(\mathrm{MJ} / \mathrm{m}^{2}\right)\end{array}$ & $\begin{array}{r}\text { Rainfal } \\
(\mathrm{mm})\end{array}$ \\
\hline Arua & 3.05 & 30.92 & 1,211 & 1.9 & 29 & 17 & 88 & 43 & 19.4 & 839 \\
\hline Kapchorwa & 1.21 & 34.39 & 1,997 & 2.8 & 23 & 13 & 93 & 50 & 21.2 & 1,508 \\
\hline Bulindi & 1.48 & 31.44 & 1,209 & 2.1 & 29 & 11 & 98 & 32 & 19.3 & 1,210 \\
\hline Entebbe & 0.05 & 32.45 & 1,155 & 1.9 & 26 & 18 & 87 & 52 & 18.7 & 1,368 \\
\hline Gulu & 2.78 & 32.28 & 1,105 & 2.4 & 29 & 19 & 79 & 43 & 20.7 & 1,537 \\
\hline Kabale & -1.25 & 29.98 & 1,869 & 2.2 & 24 & 12 & 95 & 44 & 17.2 & 1,015 \\
\hline Kabanyolo & 0.45 & 32.62 & 1,170 & 1.9 & 28 & 18 & 88 & 46 & 18.7 & 1,366 \\
\hline Kasese & 0.18 & 30.10 & 961 & 2.1 & 31 & 18 & 81 & 38 & 17.9 & 1,128 \\
\hline Kibbanda-Rakai & -0.84 & 31.64 & 1,285 & 2.1 & 27 & 14 & 96 & 44 & 17.8 & 1,217 \\
\hline Kitgum & 3.28 & 32.89 & 953 & 2.4 & 31 & 18 & 82 & 37 & 20.6 & 1,141 \\
\hline Lira & 2.32 & 32.93 & 1,091 & 2.4 & 31 & 16 & 90 & 36 & 20.7 & 1,541 \\
\hline Masindi & 1.68 & 31.72 & 1,147 & 1.9 & 30 & 18 & 84 & 42 & 19.2 & 869 \\
\hline Mbarara & -0.60 & 30.68 & 1,402 & 2.0 & 28 & 16 & 89 & 43 & 18.1 & 851 \\
\hline Namulonge & 0.53 & 32.62 & 1,160 & 1.9 & 29 & 16 & 94 & 43 & 18.7 & 1,381 \\
\hline Soroti & 1.72 & 33.62 & 1,123 & 2.3 & 31 & 19 & 79 & 39 & 21.5 & 983 \\
\hline Tororo & 0.68 & 34.17 & 1,171 & 2.2 & 30 & 17 & 78 & 37 & 21.2 & 1,328 \\
\hline
\end{tabular}


net radiation at crop surface $\left(\mathrm{MJ} / \mathrm{m}^{2} /\right.$ day); $G$ = soil heat flux density at soil surface $\left(\mathrm{MJ} / \mathrm{m}^{2} /\right.$ day); $T$ = mean daily air temperature at $1.5-2.5$ $\mathrm{m}$ height $\left({ }^{\circ} \mathrm{C}\right) ; u_{2}=$ mean daily wind speed at $2 \mathrm{~m}$ height $(\mathrm{m} / \mathrm{s}) ;$ es $=$ saturation vapor pressure at $1.5-2.5 \mathrm{~m}$ height $(\mathrm{kPa}) ; \mathrm{ea}=$ actual vapor pressure at $1.5-2.5 \mathrm{~m}$ height $(\mathrm{kPa})$; es $-e a=$ saturation vapor pressure deficit $(\mathrm{kPa}) ; \gamma=$ psychrometric constant $\left(\mathrm{kPa} /{ }^{\circ} \mathrm{C}\right) ; \mathrm{Cn}$ and $\mathrm{Cd}=$ constants with values of $900^{\circ} \mathrm{C} \mathrm{mm} \mathrm{s} / \mathrm{Mg} /$ day and $0.34 \mathrm{~s} / \mathrm{m}$, respectively; and $\lambda=$ latent heat of vaporization, $2.45(\mathrm{MJ} / \mathrm{kg})$. All parameters necessary for computing ETo were computed according to the procedure developed in FAO-56 by Allen et al. (1998).

Valiantzas (2012): Valiantzas' Method 1 (Val 1):

$$
\begin{aligned}
\text { ETo }= & 0.0393 \operatorname{Rs}(T \text { mean }+9.5)^{0.5}-0.19 \operatorname{Rs}^{0.6} \varphi^{0.15} \\
& +0.0061(T \text { mean }+20)(1.12 T \text { mean }-T \times \min -2)^{0.7}
\end{aligned}
$$

Valiantzas (2012): Valiantzas' Method 2 (Val 2):

$$
\begin{aligned}
\text { ETo }= & 0.0393 \mathrm{Rs}(\text { Tmean }+9.5)^{0.5}-0.19 \mathrm{Rs}^{0.6} \varphi^{0.15} \\
& +0.078(\text { Tmean }+20)(1-\mathrm{RH} / 100)
\end{aligned}
$$

Valiantzas (2012): Valiantzas' Method 3 (Val 3):

$$
\begin{aligned}
\text { ETo }= & 0.0393 \operatorname{Rs}(\text { Tmean }+9.5)^{0.5}-(\mathrm{Rs} / \mathrm{Ra})^{2} \\
& -(\text { Tmean }+20)(1-\mathrm{RH} / 100)(0.024-0.1 \text { Waero })
\end{aligned}
$$

with $\mathrm{RH}>65 \%$, Waero $=0.78 ; \mathrm{RH} \leq 65 \%$, Waero $=1.067$, where Waero is an empirical weighted factor.

Valiantzas (2013c): Valiantzas' Method 4 (Val 4):

$$
\begin{aligned}
\text { ETo }= & 0.051(1-\alpha) \operatorname{Rs}(\text { Tmean }+9.5)^{0.5}-2.4(\mathrm{Rs} / \mathrm{Ra})^{2} \\
& +0.048(\text { Tmean }+20)(1-\mathrm{RH} / 100)\left(0.5+0.536 u_{2}\right) \\
& +0.00012 \mathrm{z}
\end{aligned}
$$

Valiantzas (2013c): Valiantzas' Method 5 (Val 5):

$$
\begin{aligned}
\text { ETo }= & 0.0393 \operatorname{Rs}(T \text { mean }+9.5)^{0.5} \\
& -\left\{2.46 \operatorname{Rs~} \varphi^{0.15} /[4 \sin (2 \pi / 365-1.39) \varphi+12]^{2}+0.92\right\}^{2} \\
& -0.024(T \text { mean }+20)(1-\mathrm{RH} / 100)-0.0268 \mathrm{Rs} \\
& +0.0984(T \text { mean }+17) \times(1.03+0.00055) \\
& \times(T \times \max -T \times \min )^{2}-\mathrm{RH} / 100
\end{aligned}
$$


Valiantzas (2013c) Valiantzas' Method 6 (Val 6):

$$
\begin{aligned}
\text { ETo }= & 0.00668 \times \mathrm{Ra} \times[(T \text { mean }+9.5) \times(T \times \max -T \times \min )]^{0.5} \\
& -0.0696 \times(T \max -T \text { min })-0.024 \times(T \text { mean }+20) \\
& \times\left\{\left[(1-\mathrm{RH} / 100)-0.00455 \times \mathrm{Ra} \times(T \times \max -T \text { dew })^{(0.5)}\right.\right. \\
& +0.0984 \times(T \text { mean }+17) \times(1.03+0.0055) \\
& \left.\left.\times(T \times \max -T \times \min )^{2}\right]-\mathrm{RH} / 100\right\}
\end{aligned}
$$

Valiantzas (2013c) Valiantzas' Method 7 (Val 7):

$$
\begin{aligned}
\text { ETo }= & 0.051(1-\alpha) \operatorname{Rs}(T \text { mean }+9.5)^{0.5} \\
& -0.188(T \text { mean }+13)(\mathrm{Rs} / \mathrm{Ra}-0.194) \\
& \times(1-0.00015)(T \text { mean }+45)^{2}(\mathrm{RH} / 100)^{0.5} \\
& -0.0165 \mathrm{Rs} u^{0.7}+0.0585(T \text { mean }+17) u^{0.75} \\
& \times\left\{\left[1+0.00043(T \times \max -T \times \min )^{2}\right]^{2}\right. \\
& -\mathrm{RH} / 100\} /\left[1+0.0043(T \times \max -T \times \min )^{2}\right. \\
& +0.0001 \mathrm{z}]
\end{aligned}
$$

\section{Valiantzas (2013c) Valiantzas' Method 8 (Val 8):}

$$
\begin{aligned}
\text { ETo }= & 0.051(1-\alpha) \operatorname{Rs}(T \text { mean }+9.5)^{0.5} \\
& -2.4(\mathrm{Rs} / \mathrm{Ra})^{2}-2.4(T \text { mean }+20)(1-\mathrm{RH} / 100) \\
& -0.0165 \mathrm{Rs} u^{0.7}+0.0585(T \text { mean }+17) u^{0.75} \\
& \times\left\{\left[1+0.00043(T \times \max -T \times \mathrm{min})^{2}\right]^{2}-\mathrm{RH} / 100\right\} \\
& /\left(1+0.00043(T \times \max -T \times \mathrm{min})^{2}+0.0001 \mathrm{z}\right.
\end{aligned}
$$

Valiantzas (2013c) Valiantzas' Method 9 (Val 9):

$$
\begin{aligned}
\text { ETo }= & \left\{0 . 0 5 1 ( 1 - \alpha ) \operatorname { R s } ( T \text { mean } + 9 . 5 ) ^ { 2 } \left(2.46 \operatorname{Rs} \varphi^{0.15}\right.\right. \\
& \left.\left./[4 \sin (2 \pi \mathrm{J} / 365-1.39) \varphi+12]^{2}+0.92\right)\right\}^{2} \\
& -0.024(T \text { mean }+20)(1-\mathrm{RH} / 100)-0.0165 \mathrm{Rs} u^{0.7} \\
& +0.0585(T \text { mean }+17) u^{0.75}\{[(1.03+0.00055) \\
& \left.\left.\times(T \max -T \text { min })^{2}-\mathrm{RH} / 100\right]+0.0001 \mathrm{z}\right\}
\end{aligned}
$$

where $T \times \max , T \times \min$, and $T$ mean = daily maximum, minimum, and mean air temperature $\left({ }^{\circ} \mathrm{C}\right)$, respectively; $R H=$ daily relative humidity $(\%) ; R s=$ solar radiation $\left(\mathrm{MJ} / \mathrm{m}^{2} /\right.$ day); Ra = extraterrestrial radiation $\left(\mathrm{MJ} / \mathrm{m}^{2} /\right.$ day); $\alpha=0.25, \varphi=$ latitude of weather station in radians; and $z=$ elevation $(m)$ of weather station. 
Table 2. Acronyms Used to Determined PM-ETo Equations under Limited Data

\begin{tabular}{lll}
$\begin{array}{l}\text { Available climatic } \\
\text { variables }\end{array}$ & $\begin{array}{l}\text { Missing climatic } \\
\text { variables }\end{array}$ & $\begin{array}{l}\text { PM-ETo } \\
\text { acronym adopted }\end{array}$ \\
\hline $\begin{array}{l}\text { Tmax, Tmin, Rhmax, } \\
\text { Rhmin, u }\end{array}$ & Rs & ETo-Rs \\
Tmax, Tmin, u, Rs & Rhmax, Rhmin & ETo-RH \\
$\begin{array}{l}\text { Tmax, Tmin, Rhmax, } \\
\text { Rhmin, Rs }\end{array}$ & $\mathrm{u}$ & ETo-um \\
Tmax, Tmin, Rhmax, Rhmin & Rs, u & ETo-Rs um \\
Tmax, Tmin, u & Rs, Rhmax, Rhmin & $\begin{array}{l}\text { ETo-Rs RH } \\
\text { ETo-RH um }\end{array}$ \\
Tmax, Tmin, Rs & Rhmax, Rhmin, u & $\begin{array}{l}\text { ETo-RsTmin Um } \\
\text { Rmin }\end{array}$ \\
\hline
\end{tabular}

\section{Estimation of Daily Reference Evapotranspiration by PM-ETo Method under Limited Data}

Owing to the nonavailability of $\mathrm{Rs}, \mathrm{RH}$, or $u$ at most of the weather stations, the FAO-56 PM ETo model was evaluated using limited data, assuming daily Rs data were missing and, thus, were derived from Tmax and Tmin using the Hargreaves radiation formula detailed within the FAO-56 paper (Hargreaves and Samani 1982; Allen et al. 1998) and reported in Djaman et al. (2016b).

In locations where $\mathrm{RH}$ data are missing, ea can be estimated using the method proposed by Allen et al. (1998), assuming that dew point temperature (Tdew) is close to daily Tmin, which is usually experienced at sunrise in reference weather stations.

Owing to the nonavailability of $u$ data at most weather stations in developing countries, daily ETo was also estimated assuming that $u$ equals long-term daily average $u$ (um) measured at each weather station during the study period. The ETo acronyms adopted under conditions of missing climatic variables are presented in Table $\mathbf{2}$.

\section{Evaluation Criteria}

Comparisons were performed using graphics and simple linear regression. The RMSE, relative error (RE), and mean bias error (MBE) were also used to evaluate the simplified ETo models: 


$$
\begin{aligned}
& \text { RMSE }=\sqrt{\sum_{i=0}^{n} \frac{(P i-O i)^{2}}{n}} \\
& \text { RE }=\frac{\text { RMSE }}{\text { ETo mean }} 100 \\
& \text { MBE }=\mathrm{n}^{-1} \sum_{1}^{n} P i-O i
\end{aligned}
$$

where $P i=$ estimated ETo with PM-ETo under conditions of missing data or Valiantzas ETo models; $O i=$ ETo estimated using PM-ETo model with full data set, at ith data point; and $n=$ total number of data points.

\section{Results and Discussion}

\section{Evaluation of FAO-56 Penman-Monteith Model with Limited Data}

The PM-ETo equation was evaluated under missing $\mathrm{Rs}, \mathrm{RH}$, and $u$ conditions compared to full data set conditions. The statistical indices of the analysis are presented in Tables 3 and 4 . With a missing Rs, the Pm-ETo equation had a different performance relative to location. However, very good fitting agreement was observed, with slopes ranging from 0.92 to 1.10, RMSE and MBE varying from 0.39 to 0.72 $\mathrm{mm} /$ day and from -0.43 to $0.55 \mathrm{~mm}$ /day, respectively (Table 4). The ETo-Rs performed better at Buginyanya, Gulu, Kitgum, Lira, Soroti, and Tororo with $R^{2}$ greater than 0.80 . A relatively good performance of ETo-Rs was obtained at Arua, Kasese, Masindi, and Mbarara, with $R^{2}$ varying from 0.58 to 0.74 , and poor performance was observed at Bulindi, Kabale, and Namulongue, with $R^{2}$ lower than 0.56 (Table 3).

At the country level with all 16 weather stations pooled, ETo-Rs showed good performance compared to PM-ETo with full data with a fitting slope of almost unity (0.998) and a coefficient of determination of 0.78 [Fig. 2(a)]. Therefore, the methodology of estimating missing Rs using Eq. (6) can be accurately applied under the humid climate in Uganda. The results of this study are in agreement with those of 


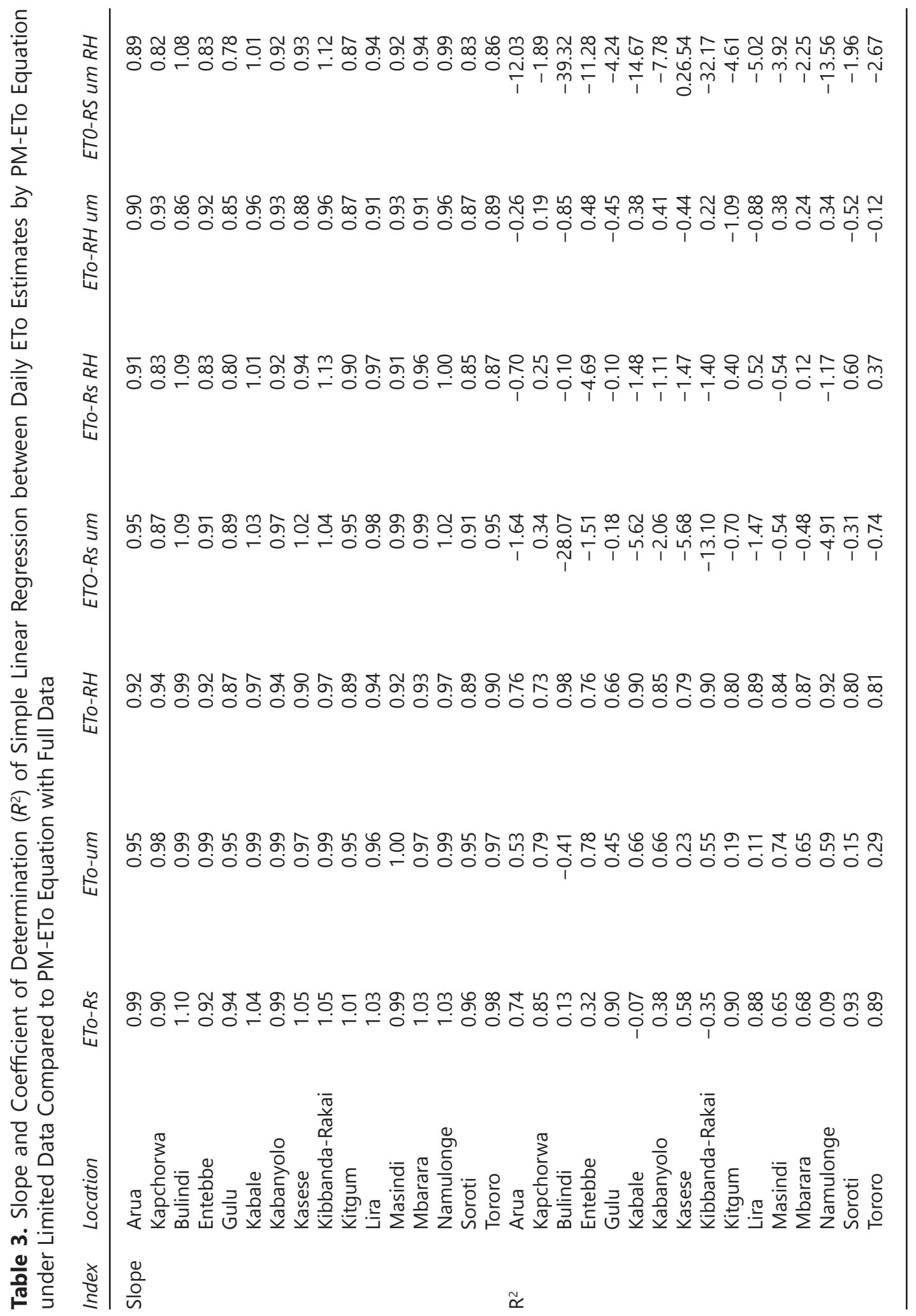




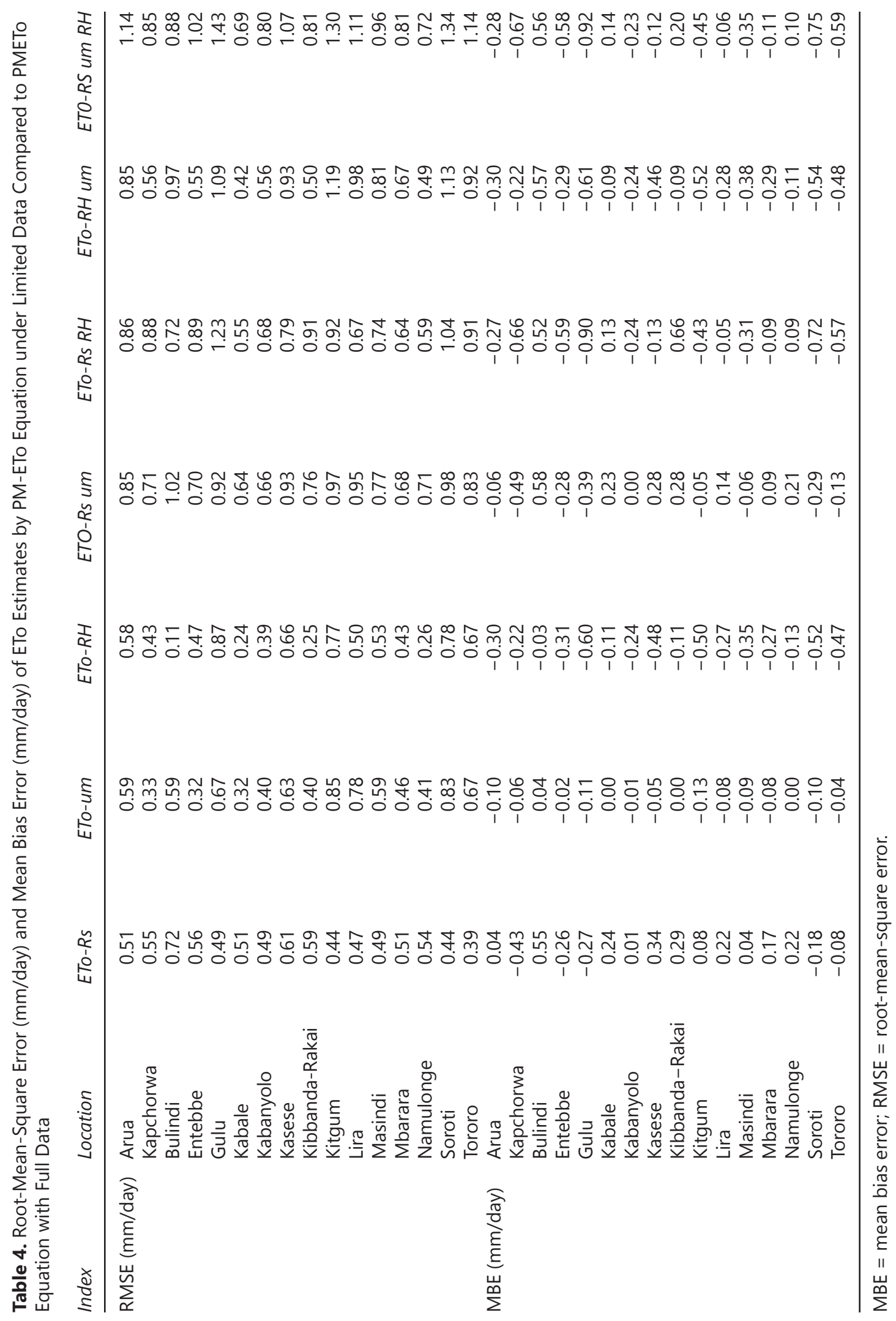



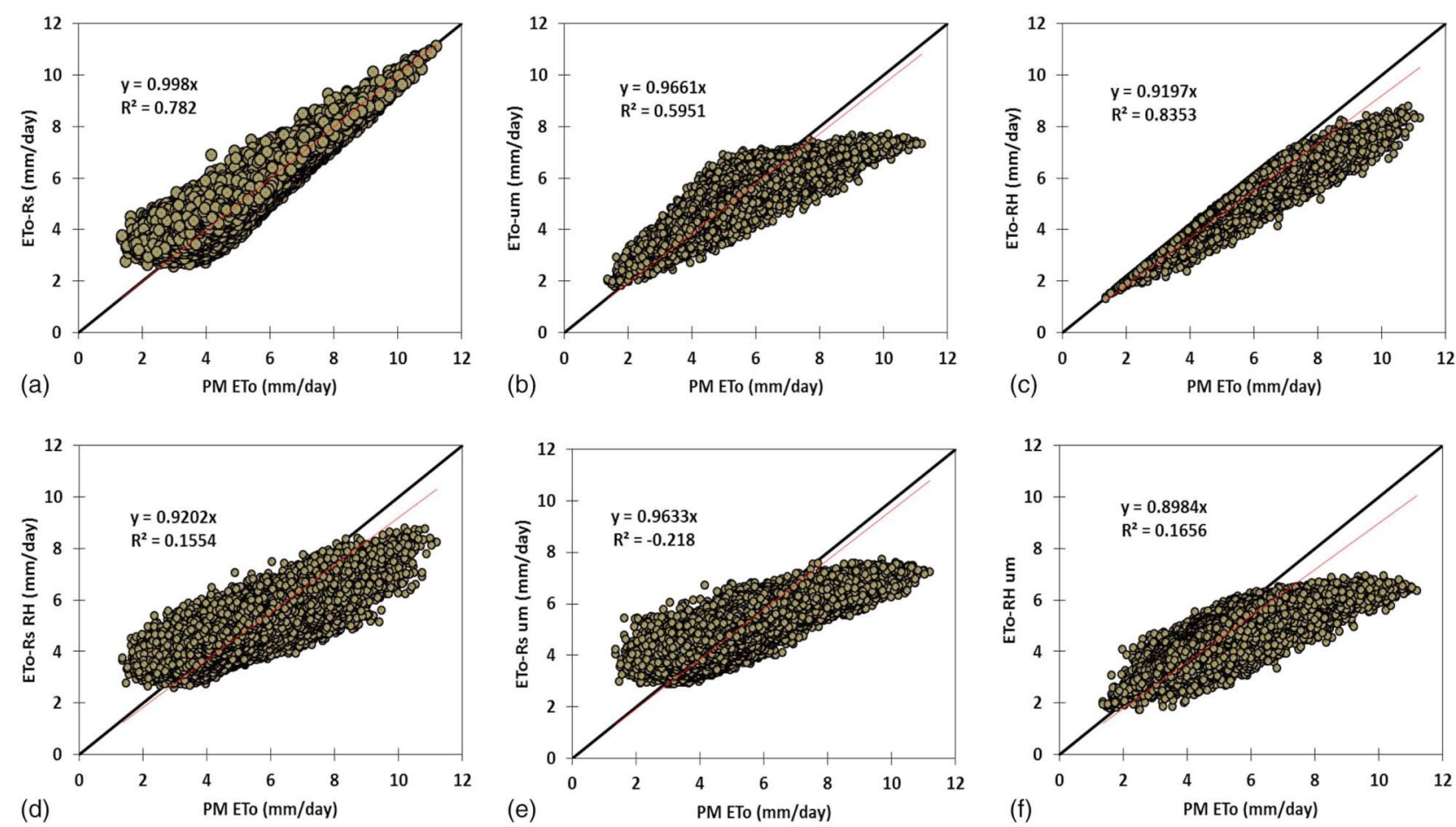

Fig. 2. Relationship between PM ETo with full data and PM ETo with missing data

Todorovic et al. (2013), who reported good performance of the PMETo model under missing Rs data with very high coefficient of correlations $R^{2} \geq 0.98$ and RMSE varying from 0.42 to $0.71 \mathrm{~mm} /$ day depending on the climatic conditions, from humid to super arid climates across the Mediterranean environment. Similar results were reported by Djaman et al. (2016b) in the semiarid climate of Burkina Faso with a fitting slope of 0.98 to 1.04 , RMSE $<0.60 \mathrm{~mm} /$ day, and MBE ranging from -0.18 to $0.02 \mathrm{~mm} /$ day. However, in the humid climate conditions of Florida, the PM-ETo equation generally overestimated the daily ETo under conditions of missing Rs data, with relatively low values of $R^{2}$ ranging from 0.37 to 0.76 (Gelcer et al. 2010). Fisher and Pringle (2013) reported that under missing Rs data, the FAO-PM model consistently overestimated daily ETo in the humid climate of the U.S. state of Mississippi. Similarly, Córdova et al. (2015) reported about $25 \%$ error in ETo estimates under missing Rs in the humid environment of Ecuador. Sentelhas et al. (2010) reported that the Rs estimation method performed better under daily Rs greater than $20 \mathrm{MJ} / \mathrm{m}^{2}$ / day in the humid climate of Canada and systematically overestimated 
Rs when actual Rs was lower than $20 \mathrm{MJ} / \mathrm{m}^{2} /$ day. Under missing Rs in Korea, Kwon and Choi (2011) reported a poor performance of the PM-ETo equation, with a large MBE of $-0.50 \mathrm{~mm} /$ day and RMSE of $0.60-0.73 \mathrm{~mm} /$ day.

Using the long-term local $u$ average values instead of missing $u$ data yielded relatively poor performance across Uganda, with low $R^{2}$ varying from -0.41 to 0.79 , the regression slope varying from 0.95 to 1.00 (Table 3), and the RMSE from 0.32 to $0.85 \mathrm{~mm} /$ day. The ETo-um underestimated daily ETo at a rate of ETo greater than $6 \mathrm{~mm} /$ day [Fig. 2(b)] and might be recommended only for ETo estimation at Buginyanya, Entebbe, and Masindi, with less variability in $u$ relative to the long-term average, where it showed the best performance. Córdova et al. (2015) indicated that the use of the global average wind speed in southern Ecuador provided a good estimate of daily ETo, even given the large discrepancies in the actual average wind speed of $3.6 \mathrm{~m} / \mathrm{s}$, against the adopted $2 \mathrm{~m} / \mathrm{s}$, suggesting that ETo calculations may not be very sensitive to wind speed in cold humid climates. Similar results were reported by Sentelhas et al. (2010) for the Great Lakes region of Canada. The use of the local average $u$ under missing $u$ data was appropriate across the semiarid climate of Burkina Faso (Djaman et al. 2016b). Similarly, Rojas and Sheffield (2013) reported that the adoption of the values obtained at the neighboring station provided good performance, with an $R^{2}$ value of $0 / 64$, a mean ratio of 0.98 , and a mean absolute error of $0.56 \mathrm{~mm} /$ day in northern Louisiana.

The PM-ETo equation performed well under missing $\mathrm{RH}$ conditions across Uganda. The fitting slopes between the ETo-RH estimates and the PM-ETo estimates with full data varied from 0.87 to 0.99 , the $R^{2}$ ranged from 0.73 to 0.98 (Table 3), the RMSE from 0.11 to $0.87 \mathrm{~mm}$ / day, and the MBE from -0.52 to $-0.03 \mathrm{~mm} /$ day (Table 4). The negative $\mathrm{MBE}$ and the fitting slope, Fig. 2(c), indicated about $8 \%$ underestimation of daily ETo by the ETo-RH method. The results are in agreement with Djaman et al. (2016b), who reported good performance of the ETo-RH method in the semiarid climate of Burkina Faso, with a regression slope of $0.90-1.14, R^{2}$ of $0.77-0.92$, RMSE of 0.07 to -0.47 $\mathrm{mm} /$ day, and MBE of -0.45 to $0.22 \mathrm{~mm} /$ day. Sentelhas et al. (2010) reported good performance of the ETo- $\mathrm{RH}$ method in southern Ontario (Canada) in a humid climate with regression slopes varying from 1.01 to 1.12 and $R^{2}$ from 0.76 to 0.96 . Similar results were reported 
by Popova et al. (2006) and Jabloun and Sahli (2008) under semiarid conditions. However, Córdova et al. (2015) indicated that the method provided up to $24 \%$ error on daily ETo estimation in the high-mountain environment because of overestimation of an actual vapor pressure deficit due to condensation occurring overnight in the humid climate (Allen et al. 1998). Similar results were obtained by Djaman et al. (2016a), who indicated that when air temperature is the only available datum, the PM-ETo equation overestimates daily ETo by as much as $36 \%$, with a high RMSE that varied from 0.94 to $1.52 \mathrm{~mm} /$ day in the semiarid climate of Burkina Faso. Also, in Korea, Kwon and Choi (2011) reported a larger discrepancy in daily ETo when actual vapor pressure was estimated from Tmin.

When more than one climatic variable date is missing, ETo-Rs un, ETo-Rs RH, ETo-RH um, ETo-Rsn um RH, all methods showed poor performance relative to the PM-ETo with full climatic data as presented in Figs. 2(d-f) (Tables 3 and 4). Whenever the regression slopes are close to unity, negative $R^{2}$ was obtained at almost all weather stations and very high RMSE up to $1.43 \mathrm{~mm} /$ day and MBE as low as $-0.92 \mathrm{~mm} /$ day (Table 4). The results of this study are in agreement with Cordova et al. (2015) who reported higher errors that ranged from 20 to 33\% if more than one climatic variable is missing under the humid climate in Ecuador. Trajkovic and Kolakovic (2009) indicated that air temperature and local default $u$ are the minimum data required to successfully use the PM-ETo equation under humid conditions. Poor performance of the method in Turkey was reported by Benli et al. (2010). However, Jabloun and Sahli (2008) verified that when only Tmax and Tmin are available, the FAO-PM model provided satisfactory ETo estimates as compared to the FAO-PM model using full data with $R^{2}$ greater than 0.90 and slope from 0.96 to 1.06 under semiarid conditions in Tunisia. Similarly, Popova et al. (2006) reported satisfactory performance of the PM-ETo equation when only air temperature was used under temperate climate in South Bulgaria. However, opposing results were reported by Sentelhas et al. (2010) who indicated that the PM-ETo method was still a very good option for estimating ETo for Southern Ontario under missing $\mathrm{RH}$ and $u$ data with RMSE smaller than 0.53 $\mathrm{mm} /$ day by replacing $u$ by the local long term average $u$ and deriving actual vapor pressure from temperature data. 

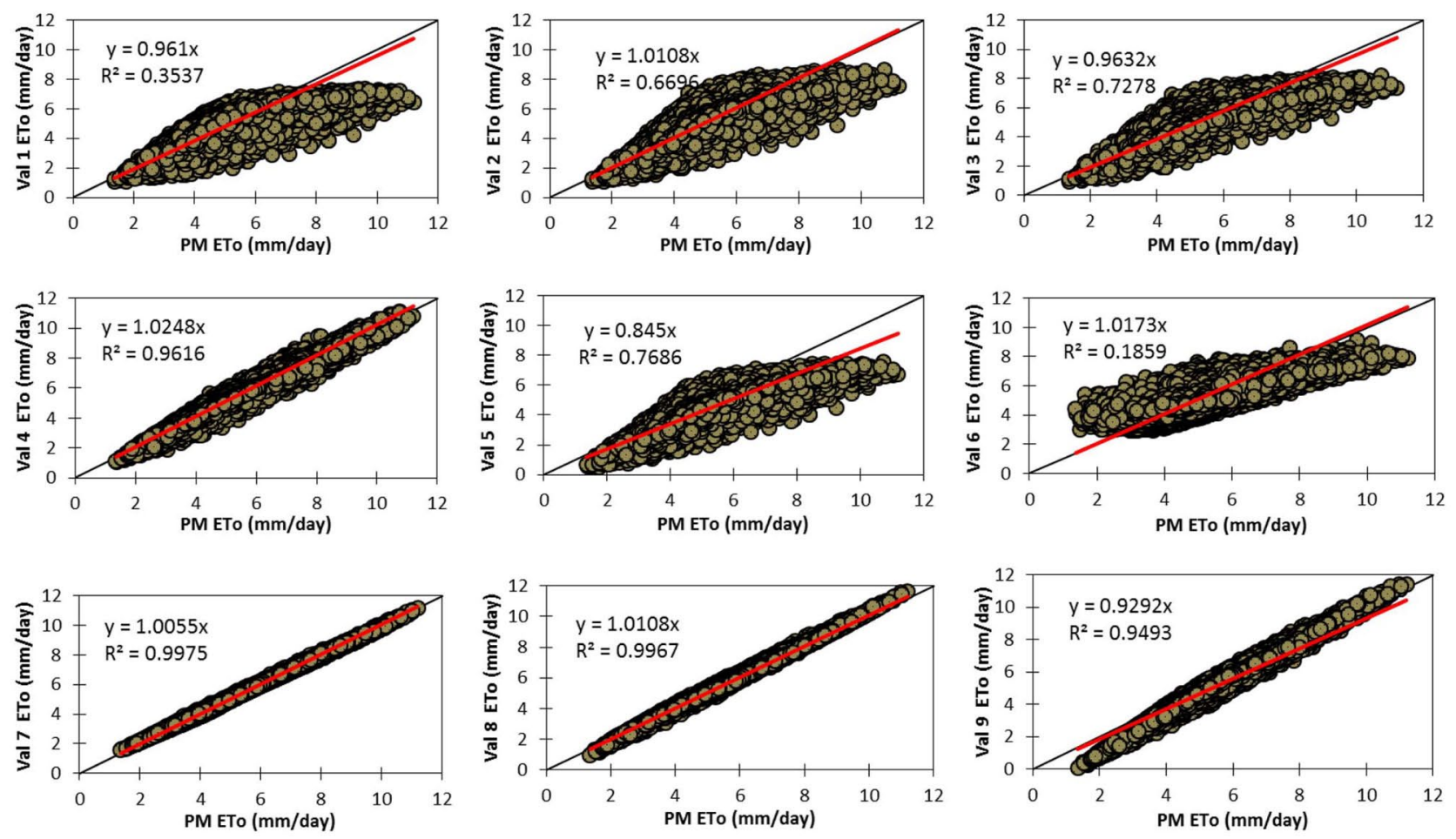

Fig. 3. Comparison of daily ETo estimated by Valiantzas' methods versus PM model at nine pooled weather stations

\section{Evaluating Valiantzas' ETo Models}

Several of Valiantzas' ETo models (Val 1, 2, 3, 4, 5, 6, 7, 8, and 9) were evaluated against the FAO-56 Penman-Monteith (PM-ETo) model with full climatic variables data. The statistical indices used, including simple linear regressions slope, $R^{2}$, RMSE, and $\mathrm{MBE}$, for each model at each of the 16 weather stations are presented in Tables 5 and 6 . The simple linear regressions of each of Valiantzas' equations against the PM-ETo model for the pooled data of the 16 weather stations are shown in Fig. 3.

The Val 4, 7, 8, and 9 models performed better across the country with respect to the PM-ETo, with $R^{2}$ varying between 0.90 and 1.00 , the regression slope ranging from 0.88 to 1.08 , RMSE ranging from 0.06 to $0.53 \mathrm{~mm} /$ day, and MBE varying between -0.49 and $0.32 \mathrm{~mm} /$ day. Val 7 and 8 showed the most accurate daily ETo estimation equation developed by Valiantzas across Uganda compared to the PM-ETo equation with regression slopes and $R^{2}$ both obtaining approximate unity at each of the 16 sites. The Val 7 and 8 models yielded very low 
RMSE values of $0.06-0.09 \mathrm{~mm} /$ day and $0.06-0.16 \mathrm{~mm} /$ day, and MBE of $0.017-0.064 \mathrm{~mm} /$ day and $0.004-0.118 \mathrm{~mm} /$ day, respectively. With all 16 weather stations pooled together, Val 7 and 8 presented similar results with regression slopes of 1.0055 and 1.0108 and an $R^{2}$ of 0.9975 and 0.9967 , respectively. The particularity of those methods is the similar climate data requirement $\left(\mathrm{Rs}, \mathrm{T}, \mathrm{RH}\right.$, and $\left.u_{2}\right)$ as the PMETo method and their simplicity of use relative to the PM-ETo model, which necessitates several intermediate calculations exposed to errors and mistakes. Among the four best Valiantzas models, Val 4 was the simplest and also performed well across Uganda, with regression slopes of $0.98-1.08, R^{2}$ of $0.96-0.99$, RMSE of $0.19-0.45 \mathrm{~mm} / \mathrm{day}$, and MBE of $-0.19-0.42 \mathrm{~mm} /$ day (Tables 5 and 6).

Table 5. Slope and Coefficient of Determination $\left(R^{2}\right)$ of Simple Linear Regression between Daily ETo Estimates Using Valiantzas' Equations and Daily ETo Estimates Using PM-ETo Equation

\begin{tabular}{|c|c|c|c|c|c|c|c|c|c|c|}
\hline Index & Location & Val 1 & Val 2 & Val 3 & Val 4 & Val 5 & Val 6 & Val 7 & Val 8 & Val 9 \\
\hline \multirow[t]{17}{*}{ Slope } & Arua 0.96 & 1.01 & 0.98 & 1.04 & 0.84 & 1.03 & 1.00 & 1.01 & 0.92 & \\
\hline & Kapchorwa & 1.01 & 1.04 & 0.96 & 1.10 & 0.82 & 0.89 & 1.01 & 1.03 & 0.95 \\
\hline & Bulindi & 0.98 & 0.96 & 0.88 & 0.96 & 0.85 & 1.09 & 1.01 & 1.00 & 0.91 \\
\hline & Entebbe & 1.09 & 1.15 & 1.04 & 1.08 & 0.90 & 1.01 & 1.00 & 1.01 & 0.94 \\
\hline & Gulu & 0.90 & 0.98 & 0.95 & 1.04 & 0.81 & 0.96 & 1.00 & 1.01 & 0.93 \\
\hline & Kabale & 0.98 & 1.00 & 0.96 & 1.05 & 0.80 & 1.07 & 1.02 & 1.02 & 0.88 \\
\hline & Kabanyolo & 1.04 & 1.08 & 1.02 & 1.05 & 0.88 & 1.06 & 1.01 & 1.01 & 0.92 \\
\hline & Kasese & 0.05 & 1.02 & 0.97 & 1.01 & 0.85 & 1.09 & 1.01 & 1.00 & 0.92 \\
\hline & Kibbanda-Rakai & 1.01 & 1.02 & 0.96 & 1.03 & 0.83 & 1.07 & 1.01 & 1.01 & 0.89 \\
\hline & Kitgum & 0.88 & 0.94 & 0.92 & 1.00 & 0.81 & 0.98 & 1.01 & 1.01 & 0.94 \\
\hline & Lira & 0.92 & 0.94 & 0.90 & 0.98 & 0.83 & 0.99 & 1.01 & 1.01 & 0.94 \\
\hline & Masindi & 0.96 & 1.02 & 0.99 & 1.03 & 0.86 & 1.05 & 1.01 & 1.01 & 0.92 \\
\hline & Mbarara & 0.98 & 1.02 & 0.98 & 1.03 & 0.84 & 1.06 & 1.01 & 1.01 & 0.92 \\
\hline & Namulonge & 1.05 & 1.06 & 0.98 & 1.03 & 0.88 & 1.08 & 1.01 & 1.01 & 0.91 \\
\hline & Soroti & 0.92 & 1.00 & 0.96 & 1.02 & 0.85 & 0.97 & 1.00 & 1.01 & 0.95 \\
\hline & Tororo & 0.96 & 1.04 & 0.99 & 1.03 & 0.88 & 1.01 & 1.00 & 1.02 & 0.96 \\
\hline & Arua & 0.32 & 0.78 & 0.82 & 0.98 & 0.82 & 0.21 & 1.00 & 1.00 & 0.94 \\
\hline \multirow[t]{15}{*}{$R^{2}$} & Kapchorwa & 0.49 & 0.80 & 0.84 & 0.99 & 0.86 & 0.53 & 0.99 & 0.99 & 0.95 \\
\hline & Bulindi & 0.45 & 0.52 & 0.47 & 0.91 & 0.51 & -14.65 & 1.00 & 0.99 & 0.92 \\
\hline & Entebbe & 0.65 & 0.84 & 0.85 & 0.99 & 0.83 & -0.05 & 1.00 & 1.00 & 0.92 \\
\hline & Gulu & 0.04 & 0.62 & 0.69 & 0.98 & 0.72 & 0.34 & 1.00 & 1.00 & 0.96 \\
\hline & Kabale & 0.68 & 0.79 & 0.80 & 0.98 & 0.79 & -2.47 & 0.99 & 1.00 & 0.90 \\
\hline & Kabanyolo & 0.61 & 0.77 & 0.77 & 0.98 & 0.79 & 0.31 & 1.00 & 1.00 & 0.92 \\
\hline & Kasese & 0.26 & 0.62 & 0.69 & 0.97 & 0.67 & -1.34 & 1.00 & 1.00 & 0.93 \\
\hline & Kibbanda-Rakai & 0.63 & 0.75 & 0.78 & 0.97 & 0.75 & -5.15 & 1.00 & 0.99 & 0.90 \\
\hline & Kitgum & 0.36 & 0.44 & 0.55 & 0.97 & 0.54 & 0.13 & 1.00 & 1.00 & 0.96 \\
\hline & Lira & -0.11 & 0.47 & 0.58 & 0.96 & 0.62 & -0.29 & 1.00 & 1.00 & 0.96 \\
\hline & Masindi & 0.41 & 0.69 & 0.74 & 0.97 & 0.80 & 0.30 & 1.00 & 1.00 & 0.95 \\
\hline & Mbarara & 0.45 & 0.73 & 0.80 & 0.97 & 0.82 & 0.19 & 1.00 & 1.00 & 0.93 \\
\hline & Namulonge & 0.63 & 0.75 & 0.75 & 0.97 & 0.76 & -1.41 & 1.00 & 1.00 & 0.91 \\
\hline & Soroti & -0.24 & 0.41 & 0.49 & 0.97 & 0.59 & 0.23 & 1.00 & 1.00 & 0.97 \\
\hline & Tororo & 0.24 & 0.57 & 0.55 & 0.97 & 0.69 & 0.05 & 1.00 & 1.00 & 0.96 \\
\hline
\end{tabular}


Table 6. Root-Mean-Square Error (mm/day) and Mean Bias Error (mm/day) of ETo Estimates Using Valiantzas' Equations Compared to PM-ETo Equation

\begin{tabular}{|c|c|c|c|c|c|c|c|c|c|c|}
\hline Index & Location & Val 1 & Val 2 & Val 3 & Val 4 & Val 5 & Val 6 & Val 7 & Val 8 & Val 9 \\
\hline \multirow[t]{16}{*}{ RMSE (mm/day) } & Arua & 0.75 & 0.55 & 0.47 & 0.24 & 0.87 & 0.74 & 0.06 & 0.10 & 0.53 \\
\hline & Kapchorwa & 0.51 & 0.42 & 0.35 & 0.45 & 0.86 & 0.65 & 0.09 & 0.16 & 0.33 \\
\hline & Bulindi & 0.60 & 0.61 & 0.76 & 0.31 & 0.86 & 1.01 & 0.07 & 0.07 & 0.53 \\
\hline & Entebbe & 0.63 & 0.75 & 0.39 & 0.34 & 0.57 & 0.61 & 0.05 & 0.07 & 0.40 \\
\hline & Gulu & 0.96 & 0.67 & 0.64 & 0.27 & 1.13 & 0.73 & 0.06 & 0.09 & 0.47 \\
\hline & Kabale & 0.44 & 0.38 & 0.37 & 0.22 & 0.85 & 0.68 & 0.09 & 0.09 & 0.55 \\
\hline & Kabanyolo & 0.57 & 0.61 & 0.45 & 0.26 & 0.68 & 0.72 & 0.06 & 0.07 & 0.48 \\
\hline & Kasese & 0.82 & 0.66 & 0.57 & 0.21 & 0.91 & 1.01 & 0.07 & 0.08 & 0.52 \\
\hline & Kibbanda-Rakai & 0.53 & 0.47 & 0.42 & 0.19 & 0.81 & 0.78 & 0.06 & 0.07 & 0.55 \\
\hline & Kitgum & 1.19 & 0.89 & 0.86 & 0.26 & 1.27 & 0.85 & 0.07 & 0.09 & 0.49 \\
\hline & Lira & 0.98 & 0.81 & 0.85 & 0.30 & 1.14 & 0.86 & 0.07 & 0.09 & 0.47 \\
\hline & Masindi & 0.74 & 0.63 & 0.56 & 0.26 & 0.84 & 0.79 & 0.06 & 0.08 & 0.51 \\
\hline & Mbarara & 0.65 & 0.54 & 0.44 & 0.23 & 0.82 & 0.72 & 0.07 & 0.09 & 0.50 \\
\hline & Namulonge & 0.57 & 0.55 & 0.44 & 0.19 & 0.69 & 0.78 & 0.06 & 0.06 & 0.49 \\
\hline & Soroti & 1.03 & 0.81 & 0.78 & 0.26 & 1.09 & 0.85 & 0.06 & 0.10 & 0.39 \\
\hline & Tororo & 0.77 & 0.72 & 0.67 & 0.27 & 0.87 & 0.78 & 0.06 & 0.11 & 0.36 \\
\hline \multirow[t]{16}{*}{ MBE (mm/day) } & Arua & -0.04 & 0.119 & -0.03 & 0.171 & -0.7 & 0.2767 & 0.032 & 0.045 & -0.47 \\
\hline & Kapchorwa & 0.092 & 0.207 & -0.14 & 0.416 & -0.78 & -0.435 & 0.023 & 0.118 & -0.25 \\
\hline & Bulindi & -0.06 & -0.16 & -0.51 & -0.19 & -0.66 & 0.5957 & 0.062 & 0.004 & -0.48 \\
\hline & Entebbe & 0.39 & 0.619 & 0.18 & 0.319 & -0.44 & 0.1197 & 0.017 & 0.05 & -0.32 \\
\hline & Gulu & -0.36 & -0.01 & -0.16 & 0.195 & -0.92 & -0.084 & 0.008 & 0.05 & -0.41 \\
\hline & Kabale & -0.06 & 0.008 & -0.16 & 0.183 & -0.78 & 0.3718 & 0.064 & 0.067 & -0.5 \\
\hline & Kabanyolo & 0.205 & 0.373 & 0.083 & 0.21 & -0.53 & 0.3488 & 0.038 & 0.033 & -0.42 \\
\hline & Kasese & -0.17 & 0.163 & -0.08 & 0.056 & -0.68 & 0.6296 & 0.047 & 0.006 & -0.45 \\
\hline & Kibbanda-Rakai & 0.072 & 0.089 & -0.17 & 0.108 & -0.69 & 0.4092 & 0.045 & 0.03 & -0.49 \\
\hline & Kitgum & -0.47 & -0.2 & -0.33 & 0.005 & -0.96 & 0.0535 & 0.019 & 0.031 & -0.43 \\
\hline & Lira & -0.28 & -0.2 & -0.43 & -0.09 & -0.86 & 0.1556 & 0.05 & 0.031 & -0.41 \\
\hline & Masindi & -0.06 & 0.19 & 0.032 & 0.153 & -0.65 & 0.3661 & 0.042 & 0.036 & -0.45 \\
\hline & Mbarara & -0.02 & 0.149 & -0.06 & 0.142 & -0.68 & 0.3962 & 0.052 & 0.052 & -0.44 \\
\hline & Namulonge & 0.235 & 0.266 & -0.05 & 0.114 & -0.54 & 0.4442 & 0.047 & 0.024 & -0.43 \\
\hline & Soroti & -0.23 & 0.128 & -0.1 & 0.156 & -0.75 & 0.0036 & 0.024 & 0.053 & -0.32 \\
\hline & Tororo & -0.1 & 0.297 & 0.027 & 0.186 & -0.6 & 0.2066 & 0.027 & 0.074 & -0.26 \\
\hline
\end{tabular}

$\mathrm{MBE}=$ mean bias error; $\mathrm{RMSE}=$ root-mean-square error.

Val 9 performed satisfactorily compared to the other Valiantzas ETo models with limited data; however, it underestimated the daily ETo across the country, with $R^{2}$ varying between 0.90 and 0.97 and RMSE between 0.33 and $0.55 \mathrm{~mm} /$ day, and MBE ranging from -0.50 to -0.25 $\mathrm{mm} /$ day (Table 6 ). These results confirmed the findings of previous studies by Djaman et al. $(2015,2016 b)$, who reported full agreement between the Valiantzas ETo estimates and the PM-ETo estimates with full climatic data sets in the semiarid climate of the Senegal River basin and across Burkina Faso. Val 4 performed better at all weather stations in Burkina Faso, with fitting slopes from 1.05 to 1.18 and $R^{2}$ as high as 0.93 (Djaman et al. 2016b). Previously, Djaman et al. (2015) reported 
that Valiantzas' equation with full data could serve as an alternative method to the PM-ETo equation in the Senegal River valley. The results of this study are also in agreement with Kisi (2014), who reported that Valiantzas' equation with full weather data performed better than other empirical methods at $75 \%$ of weather stations in Turkey. These results also confirmed the study of Valipour (2015), who concluded that Val 4 ( $T, R s, R H, u_{2}$ ) was the most precise method for south-central and southeastern Iran, and Val $7\left(\mathrm{~T}, \mathrm{Rs}, \mathrm{RH}, u_{2}\right)$ was more applicable in western, eastern, and northern Iran.

The Valiantzas ETo models with limited data (Val 1, 2, 3, 5, and 6) yielded the poorest results across $U$ ganda, with $R^{2}$ varying between 0 and 0.84 , the slope varying from 0.05 to 1.09 , RMSE from 0.35 to 1.27 $\mathrm{mm} /$ day, and MBE varying between -0.96 and $0.63 \mathrm{~mm} /$ day. Among these, Val $6(T, R H)$ presented the worst results, with $R^{2}$ varying between 0 and 0.53 , regression slope from 0.21 to 1.09 , RMSE from 0.61 to $1.01 \mathrm{~mm} /$ day, and MBE from -0.43 to $0.63 \mathrm{~mm} /$ day (Tables 5 and 6). This result is in agreement with the findings of Djaman et al. (2016a), who reported that the worst performance of Valiantzas' equation in Sahelian conditions was observed under the missing Rs and $u$ scenario. Val 6 ETo showed poor performance across Burkina Faso, with $17 \%$ of ETo overestimation and high RMSE ranging from 0.73 to 2.2 $\mathrm{mm} /$ day (Djaman et al. 2016b). The results of this study contrast with the findings of Valipour (2015), who reported Val 2 (T, Rs, RH) as the best method among limited data methods; however, he indicated that the best weather conditions for Valiantzas' methods are when Rs $>24.2 \mathrm{MJ}=\mathrm{m}^{2}=$ day, temperature $16-18^{\circ} \mathrm{C}, \mathrm{RH} 40-50 \%$, and $u 1.50$ $2.50 \mathrm{~m}=\mathrm{s}$.

Val 3 (T, Rs, RH) produced the best results among Valiantzas' ETo models with limited data, with $R^{2}$ varying from 0.49 to 0.85 and RMSE between 0.35 and $0.86 \mathrm{~mm} /$ day (Tables 5 and 6 ). Ahooghalandari et al. (2016) reported that Val 1 and 2 were suitable in their original forms for ETo estimation in Western Australia and showed better performance after local calibration. Valiantzas' method also produced the best results among six temperature-based ETo equations and required no calibration to the U.S. Southeast, showing a higher correlation and lower error at 92 automated weather stations in Florida, Georgia, and North Carolina (Gelcer et al. 2010). In light of these results, in the context of limited data, Val 3 could be recommended for 
daily ETo estimation under conditions of missing data in Uganda. If full climatic data are available, then Val 7, 8, and 4 could be the first choice owing to their simplicity and accuracy. However, under limited data conditions and if at all possible, Valiantzas' ETo models should be compared to the PM-ETo model.

\section{Can the Valiantzas Equations Be Alternatives to the PM-ETo Model under Humid Climate Conditions?}

The original PM-ETo model with full data is equivalent to Val 4, 7, 8 , and 9 in terms of the number of climatic variables required (i.e., Rs, $\mathrm{T}, \mathrm{RH}$, and $u_{2}$ ). The ETo-um model corresponds to Val 3 and 5 with missing $u$ data conditions. The ETo- $\mathrm{RH}$-um model is equivalent to Val 1 and 2, whereas the ETo-Rs-um model corresponds to Val 6. Across Uganda, the PM-ETo model had poor performance under conditions of limited or missing climatic data, as did Valiantzas' equation without full climatic data, and they are not recommended. While the four Valiantzas equations with full climatic data (Val 4, 7, 8, and 9) showed good performance across the study area (Fig. 3) with no geographical effect, Val 7, which obtained a regression slope of 1.0055 and $R^{2}$ of 0.9975 , should be the first choice as an alternative method to the PM-ETo for daily ETo estimation. Val 8 might also be used for accurate estimation of daily ETo across Uganda (regression slope of 1.0108 and $\left.R^{2}=0.9976\right)$. However, Val 4 could be the first choice for its simplicity and depending on the level of professional expertise and the technical ability of the user. Val 9 should be the last option because it underestimated the daily ETo mostly at ETo rates less than $6 \mathrm{~mm} /$ day. Our results are not in full agreement with those of other studies that showed the applicability of Valiantzas' equation under missing data conditions. Djaman et al. $(2015,2016 b)$ reported full agreement between Valiantzas' ETo estimates and the PM-ETo estimates with full climatic data set in the semiarid climate of the Senegal River basin and across Burkina Faso. Val 3 and 4 (T, Rs, RH), both with missing $u$, were revealed to be the best methods among the limited data methods in 18 provinces of Iran; Val $4\left(\mathrm{~T}, \mathrm{Rs}, \mathrm{RH}, u_{2}\right)$ was more suitable for southcentral Iran, and Val $7\left(T, R s, R H, u_{2}\right)$ was more applicable in western, eastern, and northern Iran. The most precise method was Val 4 (T, Rs, $\mathrm{RH}, u_{2}$ ) for southeastern Iran (Valipour 2015). Ahooghalandari et al. 
(2016) reported that Val 1 and 2 were relatively suitable ETo methods and showed better performance after local calibration in the Pilbara region in Australia.

\section{Conclusions}

This study evaluated the PM-ETo and nine Valiantzas ETo equations under conditions of limited data in the humid climate of Uganda. The PM-ETo performed well under missing Rs and relatively well under missing $\mathrm{RH}$, with $8 \%$ daily ETo underestimation countrywise. Daily ETo was systematically underestimated at a daily ETo higher than 6 $\mathrm{mm}$ /day under missing wind speed. The PM-ETo showed poor performance when more than one climatic variable was missing and is not recommended for use; an alternative equation is recommended for daily ETo estimation across Uganda. Across Uganda, Valiantzas' equations had poor performance under limited or missing climatic data, as did the PM-ETo equations without full climatic data and so are not recommended. With a complete climatic data set, four of Valiantzas equations (Val 4, 7, 8, and 9) showed great performance across the study area; however, Val $7\left(T, R s, R H, u_{2}\right)$ and Val $8\left(T, R s, R H, u_{2}\right)$, which produced regression slopes of 1.0055 and 1.0108 and $R^{2}$ of 0.9975 and 0.9976 , respectively, might be considered the first choice as an alternative method to the PM-ETo for daily ETo estimation. In light of these results, wind speed was the most critical variable that affected daily ETo estimation in Uganda's humid climate, and the PM-ETo equation is recommended for ETo estimation under full and limited data in the humid climate of Uganda.

\section{References}

Ahooghalandari, M., Khiadani, M., and Jahromi, M. E. (2016). "Calibration of Valiantzas' reference evapotranspiration equations for the Pilbara region, Western Australia." Theor. Appl. Climatol., 1-12.

Allen, R. G., Pereira, L. S., Raes, D., and Smith, M. (1998). "Crop evapotranspiration: Guidelines for computing crop water requirements." FAO, Rome.

ASCE-EWRI (Environmental and Water Resources Institute). (2005). "The ASCE standardized reference evapotranspiration equation." Reston, VA. 
Azhar, A. H., and Perera, B. J. C. (2011). "Evaluation of reference evapotranspiration estimation methods under Southeast Australian conditions." J. Irrig. Drain. Eng., doi:10.1061/(ASCE)IR.1943-4774.0000297, 268-279.

Benli, B., Bruggeman, A., Oweis, T., and Üstün, H. (2010). "Performance of PenmanMonteith FAO56 in a semiarid highland environment." J. Irrig. Drain. Eng., doi:10.1061/(ASCE)IR.1943-4774.0000249, 757-765.

Córdova, M., Carrillo-Rojas, G., Crespo, P., Wilcox, B., and Célleri, R. (2015). "Evaluation of the Penman-Monteith (FAO 56 PM) method for calculating reference evapotranspiration using limited data. Application to the Wet Páramo of Southern Ecuador." Mountain Res. Dev., 35(3), 230-239.

Djaman, K., et al. (2015). "Evaluation of sixteen reference evapotranspiration methods under Sahelian conditions in the Senegal River Valley." J. Hydrol.: Reg. Stud., 3, 139-159.

Djaman, K., and Irmak, S. (2013). "Actual crop evapotranspiration and alfalfa- and grass-reference crop coefficients of maize under full and limited irrigation and rainfed conditions." J. Irrig. Drain. Eng., doi:10.1061/(ASCE)IR.19434774.0000559, 433-446.

Djaman, K., Irmak, S., and Futakuchi, K. (2016a). "Daily reference evapotranspiration estimation under limited data in Eastern Africa." J. Irrig. Drain. Eng., doi:10.1061/(ASCE)IR.1943-4774.0001154, 06016015.

Djaman, K., Irmak, S., Kabenge, I., and Futakuchi, K. (2016b). "Evaluation of the FAO-56 Penman-Monteith model with limited data and the Valiantzas' models for estimating reference evapotranspiration in the Sahelian conditions." J. Irrig. Drain. Eng., doi:10.1061/(ASCE)IR.1943- 4774.0001070, 04016044.

Djaman, K., Tabari, H., Balde, A. B., Diop, L., Futakuchi, K., and Irmak, S. (2016c). "Analyses, calibration and validation of evapotranspiration models to predict grass reference evapotranspiration in the Senegal River Delta." J. Hydrol. Reg. Stud., 8, 82-94.

Doorenbos, J., and Pruitt, W. O. (1977). "Guidelines for predicting crop water requirements." FAO, Rome.

Fisher, D., and Pringle, H. (2013). "Evaluation of alternative methods for estimating reference evapotranspiration." Agric. Sci., 4(8A), 51-60.

Garcia, M., Raes, D., Allen, R., and Herbas, C. (2004). "Dynamics of reference evapotranspiration in the Bolivian highlands (Altiplano)." Agric. Forest Meteorol., 125(1-2), 67-82.

Gelcer, E. M., Fraisse, C. W., and Sentelhas, P. C. (2010). "Evaluation of methodologies to estimate reference evapotranspiration in Florida." Proc. Florida State Hortic. Soc., 123, 189-195.

Hargreaves, G. H., and Allen, R. G. (2003). "History and evaluation of Hargreaves evapotranspiration equation." J. Irrig. Drain. Eng., doi:10.1061/(ASCE)07339437(2003)129:1(53), 53-63.

Hargreaves, G. H., and Samani, Z. A. (1982). "Estimating potential evapotranspiration." J. Irrig. Drain. Eng., 108(3), 223-230. 
Hargreaves, G. H., and Samani, Z. A. (1985). "Reference crop evapotranspiration from temperature." Appl. Eng. Agric., 1(2), 96-99.

Irmak, S., Irmak, A., Howell, T. A., Martin, D. L., Payero, J. O., and Copeland, K. S. (2008). "Variability analyses of alfalfa-reference to grass-reference evapotranspiration ratios in growing and dormant seasons." J. Irrig. Drain. Eng., doi:10.1061/(ASCE)0733-9437(2008)134: 2(147), 147-159.

Irmak, S., Irmak, A., and Jones, J. W. (2003). "Solar and net radiation-based equations to estimate reference evapotranspiration in humid climates." J. Irrig. Drain. Eng., doi:10.1061/(ASCE)0733-9437(2003)129:5(336), 336-347.

Jabloun, M., and Sahli, A. (2008). "Evaluation of FAO-56 methodology for estimating reference evapotranspiration using limited climatic data application to Tunisia." Agric. Water Manage., 95(6), 707-715.

Kisi, O. (2014). "Closure to 'Comparison of different empirical methods for estimating daily reference evapotranspiration in Mediterranean climate' by Ozgur Kisi." J. Irrig. Drain. Eng., doi:10.1061/(ASCE)IR.1943-4774.0000817, 07014045.

Kwon, H., and Choi, M. (2011). "Error assessment of climate variables for FAO-56 reference evapotranspiration." Meteorol. Atmos. Phys., 112(1-2), 81-90.

Li, Z., Zheng, F. L., and Liu, W. Z. (2012). "Spatiotemporal characteristics of reference evapotranspiration during 1961-2009 and its projected changes during 2011- 2099 on the Loess Plateau of China." Agric. Forest Meteorol., 154155, 147-155.

López-Urrea, R., Martín de Santa Olalla, F., Fabeiro, C., and Moratalla, A. (2006). "Testing evapotranspiration equations using lysimeter observations in a semiarid climate." Agric. Water Manage., 85(1-2), 15-26.

Martinez, C. J., and Thepadia, M. (2010). "Estimating reference evapotranspiration with minimum data in Florida, USA." J. Irrig. Drain. Eng., doi:10.1061/(ASCE) IR.1943-4774.0000214, 494-501.

McMahon, T. A., Finlayson, B. L., and Peel, M. C. (2016). "Historical developments of models for estimating evaporation using standard meteorological data." Wiley Interdiscipl. Rev. Water, 3(6), 788-818.

Mendonça, J. C., Sousa, E. F., de Bernardo, S., Dias, G. P., and Grippa, S. (2003). "Comparison of estimation methods of reference crop evapotranspiration (ETo) for Northern Region of Rio de Janeiro State, Brazil." Revista Brasileira de Engenharia Agrícola e Ambiental, 7(2), 275-279.

Popova, Z., Kercheva, M., and Pereira, L. (2006). "Validation of the FAO methodology for computing ETo with limited data. Application to south Bulgaria." Irrig. Drain., 55(2), 201-215.

Rahimikhoob, A., Behbahani, M. R., and Fakheri, J. (2012). "An evaluation of four reference evapotranspiration models in a subtropical climate." Water Resour. Manage., 26(10), 2867-2881.

Rojas, J., and Sheffield, R. (2013). "Evaluation of daily reference evapotranspiration methods as compared with the ASCE-EWRI Penman-Monteith equation using limited weather data in Northeast Louisiana." J. Irrig. Drain. Eng., doi: 10.1061/ (ASCE)IR.1943-4774.0000523, 285-292. 
Rudnick, D. R., and Irmak, S. (2014). "Impact of nitrogen fertilizer on maize evapotranspiration crop coefficients under fully-irrigated, limited irrigation, and rainfed settings." J. Irrig. Drain. Eng., doi:10.1061/(ASCE)IR 19434774.0000778, 0401403.

Sentelhas, P. C., Gillespie, T. J., and Santos, E. A. (2010). "Evaluation of FAO Penman-Monteith and alternative methods for estimating reference evapotranspiration with missing data in Southern Ontario, Canada." Agric. Water Manage., 97(5), 635-644.

Stockle, C. O., Kjelgaard, J., and Bellocchi, G. (2004). "Evaluation of estimated weather data for calculating Penman-Monteith reference crop evapotranspiration." Irrig. Sci., 23(1), 39-46.

Tabari, H., Grismer, M., and Trajkovic, S. (2013). "Comparative analysis of 31 reference evapotranspiration methods under humid conditions." Irrig. Sci., 31(2), 107-117.

Tegos, A., Efstratiadis, A., and Koutsoyiannis, D. (2013). "A parametric model for potential evapotranspiration estimation based on a simplified formulation of the Penman-Monteith equation." http://dx.doi.org/10.5772/52927 (Jul. 15, 2016).

Tegos, A., Malamos, N., and Koutsoyiannis, D. (2015). "A parsimonious regional parametric evapotranspiration model based on a simplification of the PenmanMonteith formula." J. Hydrol., 524, 708-717.

Thornthwaite, C. W. (1948). "An approach toward a rational classification of climate. Geogr. Rev., 38(1), 55-94.

Todorovic, M., Karic, B., and Pereira, L. S. (2013). "Reference evapotranspiration estimate with limited weather data across a range of Mediterranean climates." J. Hydrol., 481, 166-176.

Trajkovic, S., and Kolakovic, S. (2009). "Evaluation of reference evapotranspiration equations under humid conditions." Water Resour. Manage., 23(14), 3057-3067.

Utset, A., Farre, I., Martinez-Cob, A., and Cavero, J. (2004). "Comparing PenmanMonteith and Priestley-Taylor approaches as reference evapotranspiration inputs for modeling maize water use under Mediterranean conditions." Agric. Water Manage., 66(3), 205-219.

Valiantzas, J. D. (2006). "Simplified versions for the Penman evaporation equation using routine weather data." J. Hydrol., 331(3-4), 690-702.

Valiantzas, J. D. (2012). "Simple ET forms of Penman's equation without wind and/ or humidity data. I: Theoretical development." J. Irrig. Drain. Eng., doi:10.1061/ (ASCE)IR.1943-4774.0000520, 1-8.

Valiantzas, J. D. (2013a). "Simple ETo forms of Penman's equation without wind and/ or humidity data. I: Theoretical development." J. Irrig. Drain. Eng., doi:10.1061/(ASCE)IR.1943-4774.0000520, 1-8.

Valiantzas, J. D. (2013b). "Simple ETo forms of Penman's equation without wind and/or humidity data. II: Comparisons with reduced set-FAO and other methodologies." J. Irrig. Drain. Eng., doi:10.1061/(ASCE)IR.1943-4774.0000502, 9-19. 
Valiantzas, J. D. (2013c). "Simplified forms for the standardized FAO-56 PenmanMonteith reference evapotranspiration using limited data." J. Hydrol., 505, 13-23.

Valiantzas, J. D. (2013d). "Simplified reference evapotranspiration formula using an empirical impact factor for Penman's aerodynamic term." J. Irrig. Drain. Eng., 18(1), 108-114.

Valipour, M. (2014). "Investigation of Valiantzas' evapotranspiration equation in Iran." Theor. Appl. Climatol., 121, 1-2.

Valipour, M. (2015). "Importance of solar radiation, temperature, relative humidity, and wind speed for calculation of reference." Arch. Agron. Soil Sci., 6(2), 239-255.

Xing, Z., Chow, L., Meng, F., Rees, H. W., Monteith, J., and Lionel, S. (2008). "Testing reference evapotranspiration estimation methods using evaporation pan and modeling in maritime region of Canada." J. Irrig. Drain. Eng., doi:10.1061/ (ASCE)0733-9437(2008)134:4(417),417-424.

Xystrakis, F., and Matzarakis, A. (2011). "Evaluation of 13 empirical reference potential evapotranspiration equations on the island of Crete in southern Greece." J. Irrig. Drain. Eng., doi:10.1061/(ASCE)IR.1943-4774.0000283, 211-222. 